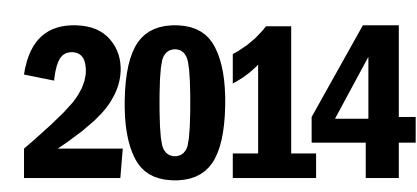

volume 11 | issue 1

an open access journal for architectural research

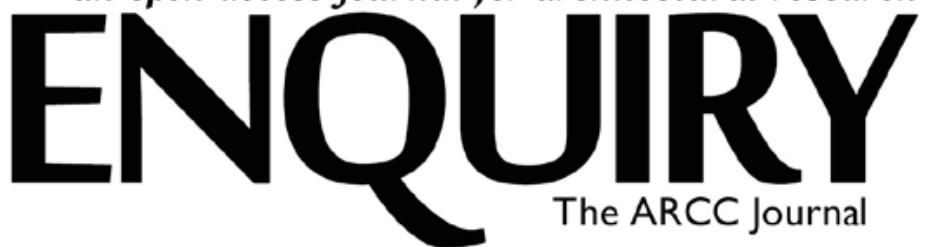

\title{
THE LABOR-SAVING KITCHEN: SOURCES FOR DESIGNS OF THE ARCHITECTS' SMALL HOME SERVICE BUREAU
}

\author{
Lisa M. Tucker
}

\begin{abstract}
The history of the kitchen has received much attention from designers and design historians. Since the writings of Catharine Beecher, designers, household engineers, and others have written about the importance of the kitchen as the center of the home. This research traces the impact of the writings of theorists such as Frederick Taylor, Georgie Boynton Child, Helen Binkerd Young, and Christine Frederick on the designs produced by the architects in the first quarter of the 20th century. Frederick's work took the concept of an efficient kitchen to a new level, applying movement studies and introducing new ideas to the kitchen layout and arrangement. In a properly laid out and equipped kitchen, steps were saved by placing kitchen cabinets, ovens and stoves, refrigerators and sinks where they were needed in the sequence of food preparation and delivery to dining table as well as clean up after the meal. In her books, she also provided advice on a variety of considerations, such as appliances and accessories, lighting and ventilation; materials, finishes, and color; and appliances and equipment. In 1919 a group of architects dedicated to improving the housing stock in the United States through good design banded together to form the Architects' Small House Service Bureau (ASHSB). Their first plan book, How to Plan, Finance and Build your Home published in 1921, also encouraged labor-saving kitchen design and provided advice on kitchen design.
\end{abstract}

The research reported here assesses how the influence of Frederick's and Boynton's advice as reflected in the work of and interpreted by Helen Binkerd Young is demonstrated in the kitchen designs of the ASHSB's first plan book. A plan content analysis instrument, developed

\section{Permissions and copyright}

Authors retain copyright and grant the journal right of first publication with the work simultaneously licensed under a Creative Commons Attribution License that allows others to share the work with an acknowledgement of the work's authorship and initial publication in this journal (Attribution-ShareAlike).

Creative Commons Attribution 3.0 Unported (CC BY 3.0)

You are free to: Share - copy and redistribute the material in any medium or format. Adapt - remix, transform, and build upon the material for any purpose, even commercially. The licensor cannot revoke these freedoms as long as you follow the license terms.

Under the following terms: Attribution - You must give appropriate credit, provide a link to the license, and indicate if changes were made. You may do so in any reasonable manner, but not in any way that suggests the licensor endorses you or your use.

No additional restrictions - You may not apply legal terms or technological measures that legally restrict others from doing anything the license permits.

\section{How to cite:}

Tucker, Lisa M. 2014. "The Labor-Saving Kitchen: Sources for Designs of the Architects' Small Home Service Bureau." Enquiry 11 (1): 52-63. using Frederick's writings and edited to include other variables from Young and Child, is used to analyze the 99 kitchens and two essays in the ASHSB's plan book. The plans and accompanying comments evidence enthusiasm for the concept of scientific management and other laborand energy-saving concepts promoted by Frederick. Many of her specific suggestions are incorporated in their kitchen designs, but there is limited evidence that ASHSB designs are only influenced by Frederick but rather include other popular labor-saving concepts of the early 20th century.

\section{INTRODUCTION}

The history of the kitchen has received much attention from interior designers and design historians. Since the writings of Catharine Beecher, designers, household engineers, and others have written about housework and management with an emphasis on efficient, labor-saving designs. This research summarizes the writings of several early 20th century theorists, such as Helen Binkerd Young, Georgie Boynton Child, and Christine Frederick as well as their potential impact on the designs produced by home architects in the first quarter of the 20th century, as seen in the plan book produced in 1921 by the Architects' Small Home Service Bureau (ASHSB). The ASHSB plans responded to a new need for the middle class-affordable and well-designed single-family houses intended to be taken care of by the housewife-following World War I.

\section{Background}

Writings about the home date back to the mid-nineteenth century and Catharine Beecher. For the first time, housework and management became the subject of study and analysis as well as a place for improvement. In her book, co-written with her sister Harriet Beecher Stowe, The American Woman's Home or Principles of Domestic Science (1869), Beecher expounds upon the role of domestic science in the running of the successful home. The first figure of the book provides a basic plan of the first floor including the kitchen (see Figure 1). Beecher compares the kitchen to a ship's galley: "The cook's galley in a steamship has every article and utensil used in cooking for two-hundred in a space not larger than this stove-room, and so arranged that 
with one or two steps the cook can reach all he uses." ${ }^{1}$ Beecher details the use of each shelf and provides trays for setting the table easily and efficiently.

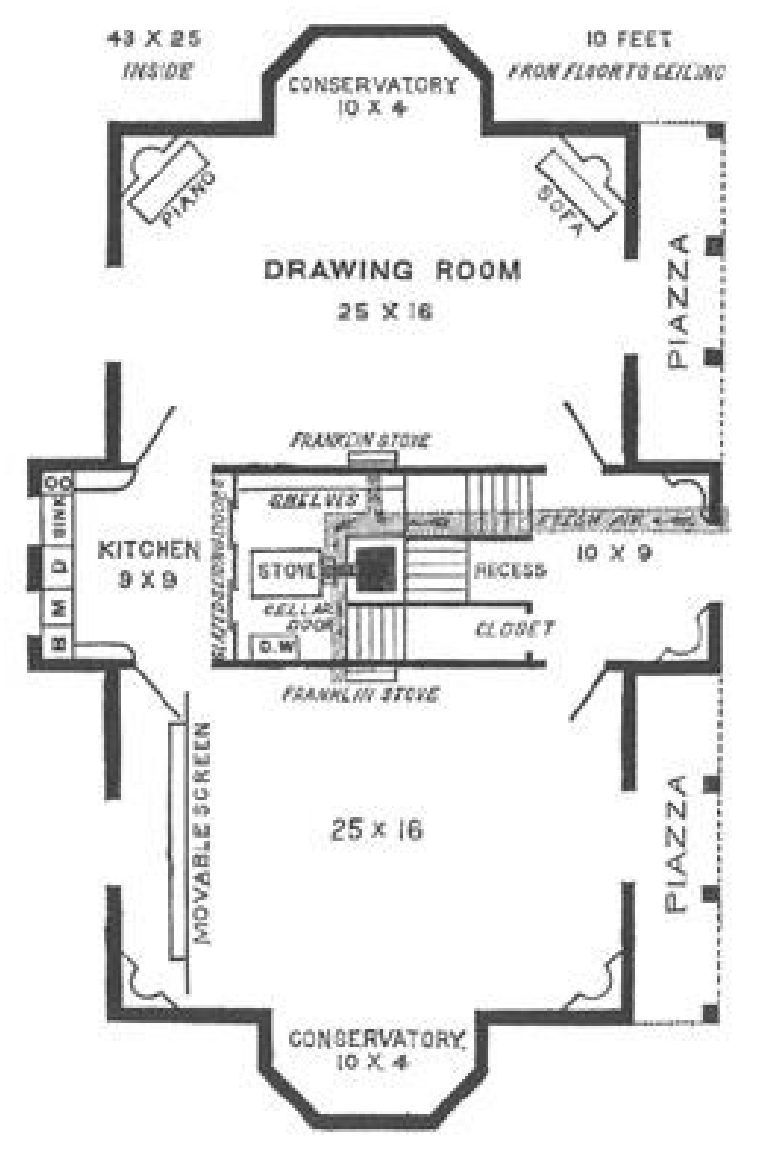

Figure 1: Catharine Beecher and Harriet Beecher Stowe. The American Woman's Home or Principles of Domestic Science (Boston: A.H. Brown and Company, 1869).

The kitchen is composed of two small rooms: a 9 feet $x 9$ feet sink area and a 9 feet $x 7$ feet stove room. Sliding doors separate the two spaces and help to keep kitchen smells contained. Areas dedicated to the convenient storage of utensils and kitchen supplies include specific storage locations noted for flour, shelves, and a pot box. Beecher places windows above the cooking counter and sink for light and ventilation. The influence of Beecher's work on the kitchen is evident in many later writers' works. For example, the placement of windows over work areas and the sink as well as dedicated storage for specific areas is present in Frederick's later work while the separation of the

1 Catharine Beecher and Harriet Beecher Stowe. The American Woman's Home or Principles of Domestic Science (Boston: A.H. Brown and Company, 1869). stove is evident in the work of Child and Young.

In the early 20th century, many people began to expand upon the work started by Beecher. Taking Frederick Taylor's principles of scientific management of industrial labor, these authors applied his ideas and concepts to the efficiency of household management. Since the majority of a housewife's labor was expended in the kitchen, this was a focus of analysis for many authors.

Taylor is credited as the founder of systems engineering and his work has had a profound impact on how industry works in North America. The principles of providing workers with the proper tools, equipment, and work areas were intended to increase efficiency and worker productivity. In Taylor's own words: "In the past man has been first; in the future the system must be first." 2 Taylor's ideas responded to a condition he called "soldiering" that took place among workers of the day, wherein they did not give $100 \%$ of their efforts. Soldiering happened because a worker did not want to be too productive and put others out of work as a result. Since work practices were taught by one worker to another, poor work methods were transmitted to new workers. However, Taylor maintained: "among the various methods and implements used in each element of each trade there is always one method and one implement which is quicker and better than any of the rest." 3 These were the very methods and tools Frederick sought to develop so that future training could be based on a "scientific rule of thumb" instead of inefficient normative practices. Taylor sought to change the burden of worker initiative from the worker (under the old management style) to the management through the use of incentives (under the scientific management style).

Taylor's work spread through American industry and was widely read by people outside of industry. Its first application to the home appears to be in Georgie Boynton Child's book The Efficient Kitchen (1914). Child and her husband traveled to Connecticut in search of improved methods of household management. In Darien,-they joined the work being done by Mr. and Mrs. Charles Barnard at their "Housekeeping Experiment Station." Charles Barnard was a technical writer by profession and was aware of Taylor's work. Writing in 1912, Child described Barnard's efforts: "Mr. Barnard saw that the next step in progressive housekeeping was to apply Mr. Taylor's principles of scientific management to the home." 4 The two primary principles upon which Barnard based his work were simplicity and coordination. The Barnards incorporated Taylor's ideas into a kitchen for two. They shared Taylor's ideas and their own implementation of these ideas

$2 \quad$ Frederick Taylor, The Principles of Scientific Management (New York: Harper Brothers, 1911), 7.

3 Ibid., 25.

$4 \quad$ Georgie Boynton Child, "The New Housekeeping Movement," The Independent Weekly Magazine, New York, Vol. LXXII (1912): 1000-1004. 
with the Childs. Working together, the Childs and Mr. Barnard planned a model kitchen for a domestic science exhibition in a large city. ${ }^{5}$ Eventually Childs became the business manager of the Housekeeping Experiment at Cedar Gate (Darien).

Following Mr. Barnard's retirement in 1911, the Childs took over the station started by the Barnards. It was from the Barnards that Child "heard of Taylor's wonderful book on scientific management." 6 Child adhered to Barnard's definition of efficient: "Efficiency has meant in the past the power to produce results. It now properly means much more. It means power to produce the best results and the lowest cost of time, labor and materials."7 In 1914 she wrote a book on designing an efficient kitchen that mentioned the idea of the scientific kitchen and her own "Housekeeping Experiment Station" (available through appointment only).

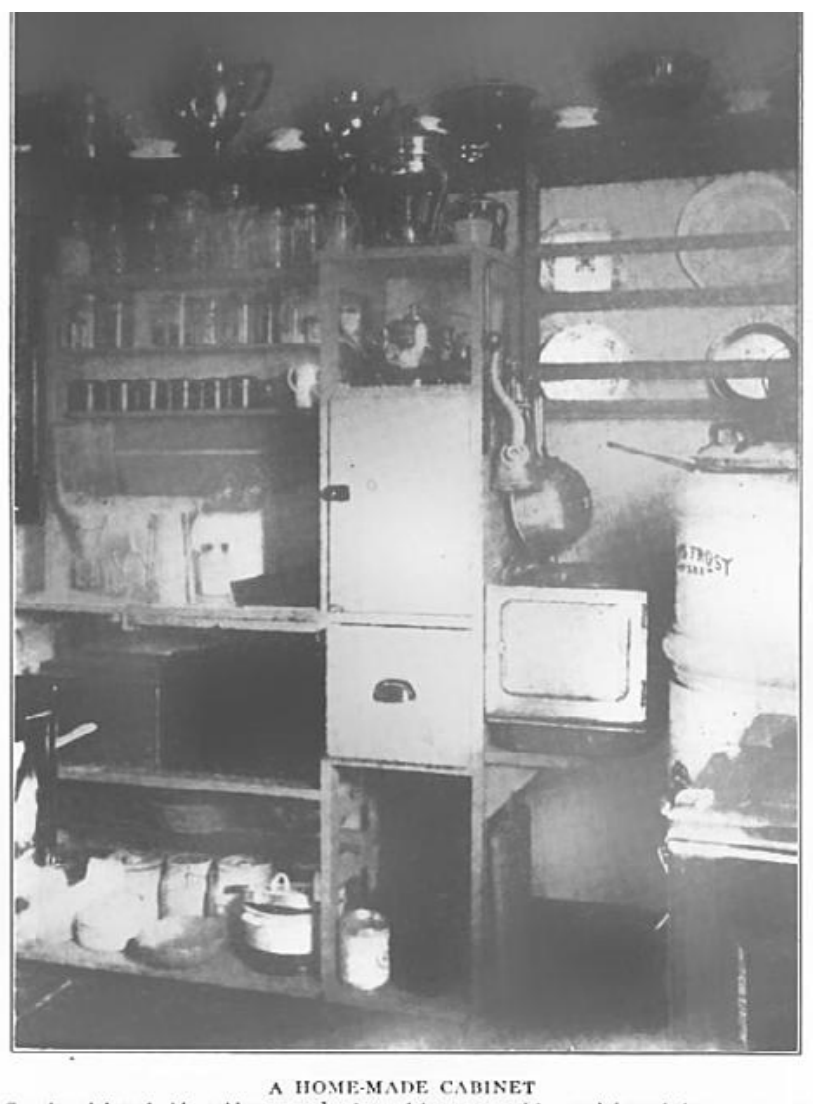

On the right of this cabinet stands the refrigerator, with revolving shelves, next to Figure 2: Housekeeping Experiment Kitchen at Darien, CT. From The Independent Weekly Magazine, New York, Vol. LXXII (1912): 1003.

$5 \quad$ The city is not specified in Child's book. The exhibit does not appear to have traveled any place else.

$6 \quad$ Georgie Boynton Child, The Efficient Kitchen: Definite Directions for the Planning, Arranging, and Equipping of the Modern Labor Saving KitchenA Practical Book for the Homemaker (New York: McBride Nast and Company, 1914), $x$.

7 Ibid., 1.
Although not a trained household engineer, Child was familiar with the writings of Taylor as introduced to her by the Barnards. Her advice included information about organization of the kitchen into areas dedicated to work processes and the use of appropriate materials and finishes. Using Taylor's approach of standardization and creating systems, Child identified the basic areas for and processes of the kitchen: work table and accessories, sink and its outfit, stove and accessories, containers and a special working shelf, provisions (cold), provisions (warm), hot water, heat, drawers for cutlery, linens and aprons, cleaning preparation area, a shelf for incoming supplies, mop and broom storage, a closet for wraps, and laundry arrangements. Child also made material suggestions: use good materials and hire a reliable contractor. More specific information about finishes included advice to never to use wallpaper (except oil cloth) and to use flat paint (rather than enamel) on walls and white enamel paint for trim. Tile was the preferred wall finish if it was affordable to the homeowner. The best choice for flooring consisted of inlaid linoleum. Child's proposed kitchen layout (see Figure 3) does not include paths of travel as later provided by Frederick but does locate the sink, stove, and icebox. Of particular note is the standalone location of the stove. ${ }^{8}$ Figure 3 shows the overall layout of the kitchen "well arranged and well equipped."

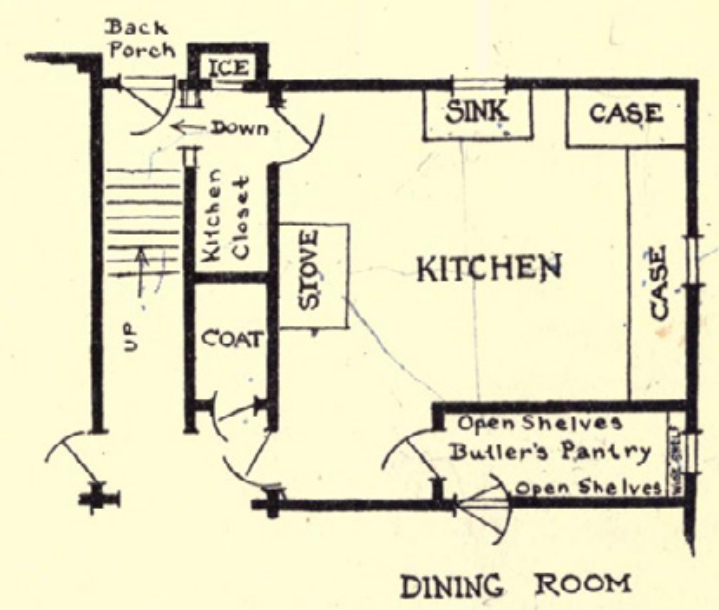

Fig. I.-Floor plan showing indirect connection between kitchen and back door and kitchen and dining room,

Figure 3: Georgie Boynton Child, The Efficient Kitchen: Definite Directions for the Planning, Arranging, and Equipping of the Modern Labor Saving Kitchen-A Practical Book for the Homemaker (New York: McBride Nast and Company, 1914).

$8 \quad$ Ibid., 21. 


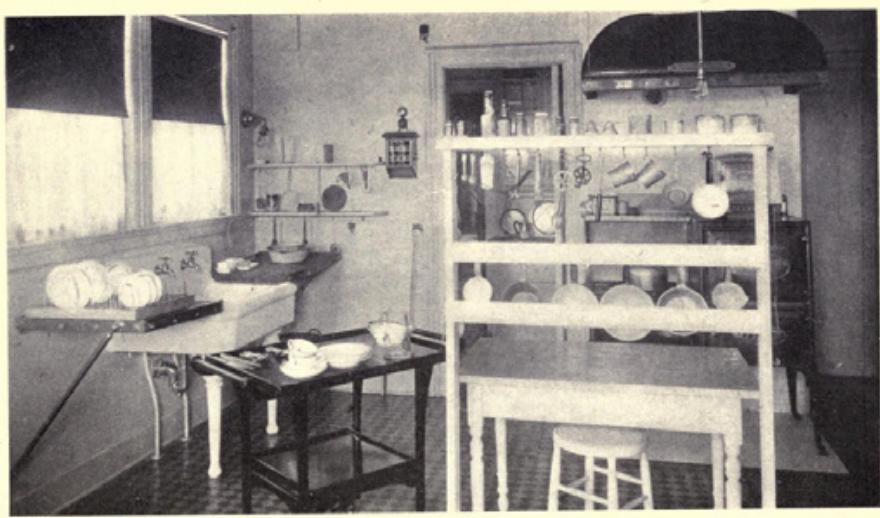

A well arranged and well equipped kitchen, New Rochelle, N. Y.

Figure 4: Georgie Boynton Child, The Efficient Kitchen: Definite Directions for the Planning, Arranging, and Equipping of the Modern Labor Saving Kitchen-A Practical Book for the Homemaker (New York: McBride Nast and Company, 1914).

\section{Child's Principles of Kitchen Efficiency:}

1. Keep nothing in the kitchen that is not used every day.

2. Things used oftenest should be most conveniently near at hand.

3. Grouping utensils and supplies should be governed by the principle of Coordination of Processes.

4. Have narrow shelves with one row of things on each.

5. Use open shelves rather than cupboards and closed closets.

6. Shelves should be at a convenient height, no lower than 12 inches nor higher than can easily be reached.

7. Nothing should be permitted to rest on the floor. This saves bending over, and facilitates cleaning the kitchen floor.

8. Have nothing in the kitchen that is not easy to keep clean.

9. Fixed equipment should be placed where the light is good.

10. Floor covering should be easy to keep clean and pleasant for the feet to rest on.

11. Small utensils should be suspended from hooks and cuphooks fastened to the wall or the edge of shelves.

12. Sink and work table should be at a convenient height for the worker.

13. There should be a special place for each thing used in the kitchen. ${ }^{9}$

Child's writing foreshadowed some of Frederick's later writings when she predicted that laundry would no longer be a part of the kitchen, although she incorrectly concluded that all laundry would eventually be outsourced to commercial vendors outside the home.

9 Ibid., 44-45.

\section{CHRISTINE FREDERICK: THE LABOR SAVING KITCHEN}

Like Child, Christine Frederick was not a household engineer or psychologist, however, she did serve as the National Secretary Consulting Household Editor of Ladies Home Journal between 1912 and 1919. Frederick's work takes the efficient kitchen to a new level using movement studies and introducing new ideas to the kitchen layout and arrangement. Her four articles in The Ladies Home Journal during 1912 formed the basis of her first book, The New Housekeeping: Efficiency Studies in Home Management (1913) and introduced management principles to housewives on a large scale. As women were running their homes by themselves without servants, they needed advice on how to do this efficiently and this is what Frederick supplied. She discussed how to use standard practices and apply motion studies to household tasks to reduce labor and steps. She enumerated a series of household activities and the time required to complete each one. For example it might take six minutes to mix a pan of biscuits while it would take twenty minutes to clean a bathroom. In the chapter on the kitchen, she indicates that a good size kitchen for a small house is 10 feet $x 12$ feet and that nearly square is the perfect shape. Frederick divided equipment and processes into two types: preparing the meal and cleaning after the meal. A diagram for proper kitchen layout illustrates her ideas for proper motion (see Figure 5). Path A indicates food preparation while B applies to clean up.
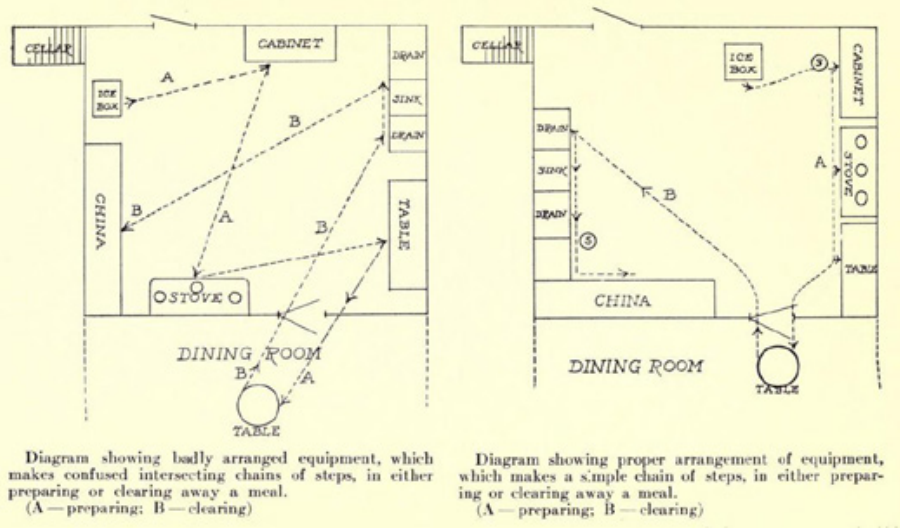

Figure 5: Christine Frederick, The New Housekeeping: Efficiency Studies in Home Management (Garden City, New York: Doubleday Page and Company, 1913).

Frederick's thinking evolved and her second book, Household Engineering: Scientific Management in the Home (1915, 1919, 1920) was used as the textbook for a correspondence course developed for women. In this book, Frederick elaborates on many of the principles for the kitchen that were proposed in her first book. The first chapter of The New Housekeeping is dedicated to the kitchen and outlines the basic components of 
the labor-saving kitchen. The plan was enhanced and developed in Household Engineering, see Figure 6.
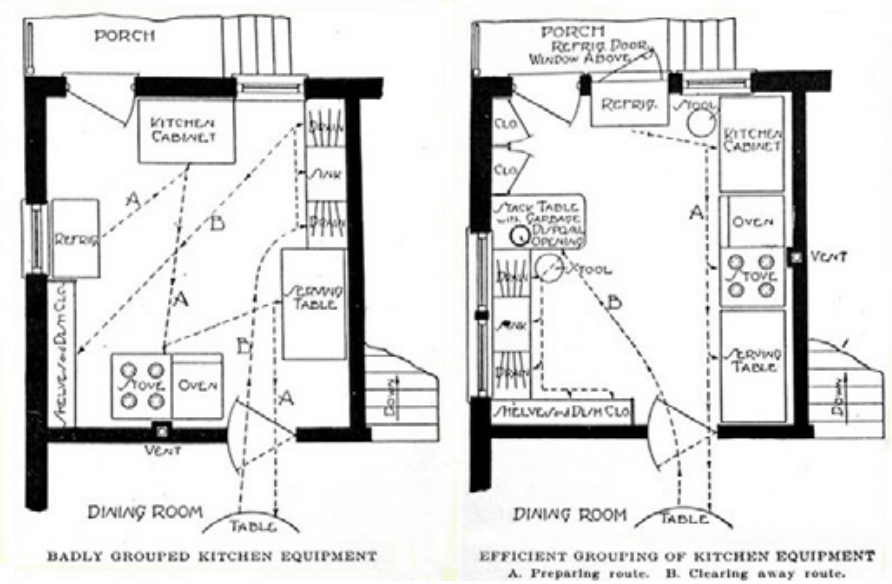

Figure 6: Christine Frederick, Household Engineering: Scientific Management in the Home (Chicago, American School of Home Economics, 1915).

\section{Kitchen Size and Layout}

Most importantly the room containing the kitchen functions could be "small and compact without loosely connected pantries and cupboards,"10 as were commonly included in house plans of the day. Oftentimes kitchens of this time period also served sitting rooms, laundry areas and workshops.

Good sizes for a kitchen in a moderately sized home included 9 feet $\times 11$ feet ( 99 square feet), 11 feet $\times 13$ feet (143 square feet), 14 feet $\times 16$ feet (224 square feet) and in larger homes with service staff and larger equipment, 18 feet $x 18$ feet (324 square feet). A more rectangular shape superseded her earlier preference for a near square shape, presumably to streamline traffic flows into a more direct path.

Several areas served the various functions of the kitchen. The main two activities in the kitchen were preparing food and clearing it away. Food preparation required collecting, preparing, cooking and serving the food. Clearing involved removing dishes, scraping them, washing them and then laying them away. Each series of activities required an appropriate arrangement of separate surfaces and equipment for this consecutive, orderly, and effective routing. In a properly laid out and equipped kitchen, steps were saved by placing refrigerator, kitchen cabinets, and work table, oven, stove, and serving table or surface where they were needed in the sequence of food preparation and delivery to dining table (A; see Figure 5). Similarly, utensils and supplies for each process

$10 \quad$ Christine Frederick, The New Housekeeping: Efficiency Studies in Home Management (Garden City, New York: Doubleday Page and Company, 1913), 19. should be grouped together. Stacking and scraping surfaces, sink and drain board, and shelving and pot closets were placed where they are needed for clean up after the meal (B). Assuming a righthanded, seated worker, Frederick stipulated that scraping be to the right of the sink and drain board and shelving be to the left. She also provided a warning: "we cannot leave the placing of the sink, stove, and cupboards entirely to the architect"11; scientific management consultants provided this information. A poorly arranged kitchen caused wasted movements and required extra energy while it also created unnecessary traffic and potential for waste. Ideally a single continuous path for food preparation and delivery (A) never crossed the single clean up path (B). Frederick advised that preparation and cleanup routes should not cross, but analysis of plans and photographs in her book show they did not adhere strictly to this dictate. Consideration is not given to cooking vegetables: getting pots from left of sink and getting water for boiling requires preparation route's crossing clean up route. Perhaps grouping supplies and equipment and sequencing processes in a route was more important. Crossing routes shouldn't create a conflict if preparation and clean up were not occurring at the same time (see Figure 6).

Additional features of the properly situated kitchen included a window at the sink and work table, a vent at the stove to allow for proper ventilation, and outside access to the refrigerator for ice delivery to avoid tracking water through the room. The sink needed a hot water supply, and Frederick encouraged garbage disposal as an integrated part of the design.

\section{Other Considerations}

According to Frederick, several areas of concern needed to be addressed in the design of the kitchen beyond the layout. These included lighting and ventilation; materials, finishes, and color; sinks, work surfaces (materials and heights), and stools; and storage and utensils.-

\section{Lighting and Ventilation}

Direct light above important work surfaces provided for a safe and efficient working space. An intense light source was needed at the table, above the stove and over the sink. In addition to artificial lighting, daylight through windows could provide lighting during the day when most housework was completed. She recommended windows be $42-46$ inches above the finished floor. In addition to providing sunlight into a space, windows on opposite walls also allowed for good cross ventilation. A second type of ventilation to be provided in the kitchen was through a chimney flue near the stove or by an overhead hood.

\section{Materials, Finishes, and Color}

The careful selection of materials and finishes contributed to

11 Christine Frederick, Household Engineering: Scientific Management in the Home. (Chicago, American School of Home Economics, 1915), 22. 
an overall clean and efficient kitchen. Sanitation was a critical issue; all surfaces needed to be easy to clean, durable, and nonabsorbent. The primary characteristics of a desirable floor finish were non-absorbent, non-porous, and easy to clean. In this vein, wood was not recommended for the kitchen floor. Three groups of sanitary flooring included linoleum, composition flooring, and tile. According to Frederick, inlaid linoleum (with pattern all the way through) was preferable to printed linoleum, and battleship linoleum (solid dull color) was the most durable. Composition flooring materials of the day included asbestos, rubber, and cement that were applied in two or more coats-these were less desirable but could be used in pantries, halls, porches, and service quarters. Frederick warned against using tile on the floor because it was too hard a surface to stand on and could be slippery. Although expensive, she preferred tile as the best wall finish. When cost or preference prohibited the use of tile, an oil cloth wall fabric could suffice as would a flat plaster with a flat paint.

Color preferences included natural-finished pine, birch, or maple or painted ivory white; putty colors were preferred over dark woods. Light tones on the walls and white on the ceiling created a lighter and more inviting space. It was important to avoid large patterns on both walls and floor. When present, the wainscot could be a slightly darker tone than the painted wall and the floor should be the darkest color of all the finishes. To accentuate the point, Frederick provided two sample color schemes that worked the best. The first scheme included a white ceiling; light warm yellow above a buff colored wainscot with a white and brown floor and ivory white woodwork. The second scheme also featured a ceiling of white with a pale apple green above a medium apple green wainscot with a white and green floor and putty colored woodwork.

\section{Sinks; Work Surfaces, and Stools}

Depending on the location of the home, different sink materials were appropriate. For a country house a slate or soapstone sinks could be used; whereas, for the modern kitchen a white enameled iron sink was preferable. Ideally the sink would have two bowls and an integral drain board on either side. If there was only one drain board, it should be at the left of the sink.

Work surfaces-including the preparation table, serving table, and other work areas-had to be durable and easily cleaned. Appropriate surfaces for the prep table included Vitrified glass, porcelain (baked enamel), monel metal or plate glass. Correct surfaces for the serving table consisted of galvanized iron, zinc, monel metal, or German silver, while drain surfaces required zinc, porcelain, German silver, or copper. Frederick recommended a vegetable preparing table surface with an 8 -inch diameter hole for waste covered in either zinc or other metal and located near the sink. She is shown working in her Applecroft Experiment
Station kitchen in Figure 7. This view illustrates several key design considerations. The finishes include tile walls and an enamel preparation surface. Items are grouped by task with a baking station adjacent to the stove. A side window provides natural light to the work station and Frederick is seated on a stool to do her work.

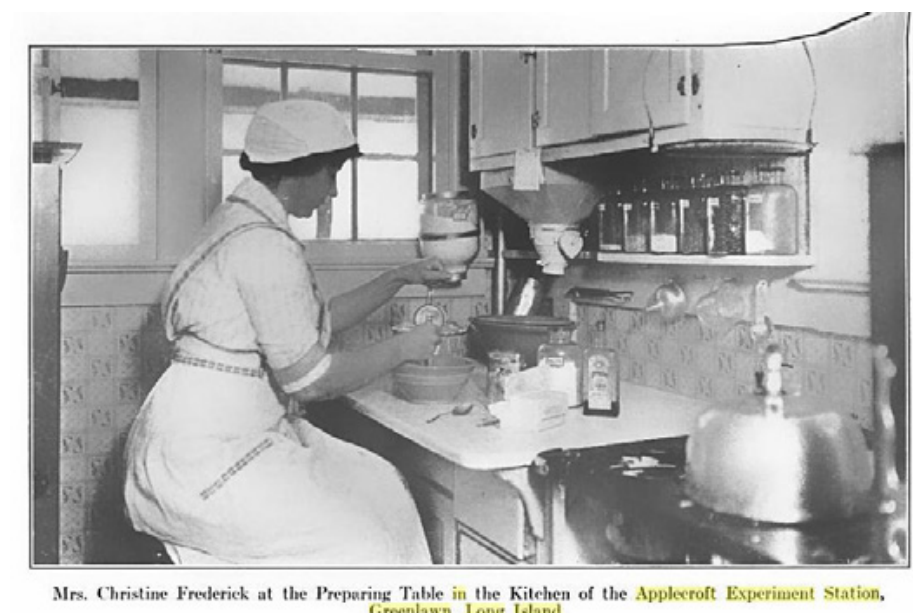

Figure 7: Christine Frederick, Household Engineering: Scientific Management in the Home (Chicago, American School of Home Economics, 1915).

In addition to materials, Frederick provided a table of recommended heights of sinks, work surface, and stool relative to the height of the worker for maximum efficiency and ease of use. While these had been included in her earlier book, they were refined for this later one. The primary change seems to be the elimination of users under 5 feet in height.

\section{Storage and Utensils}

A combination of built-ins, bins, and drawers were used to contain all the pertinent kitchen implements. Frederick provided a cadre of sizes for shelving based on specific uses. Permanent shelves and a pot or dish closet were to be located to the left of the sink-with the shelves graded in height based on use from 6 inches (row of pitchers), 8 inches (jars), to 10 inches (plates) and 14 inches (large pieces such as bread mixer, steamer, and preserving kettle). Like the shelving, bins and drawers also served the specific needs of the kitchen. Bins of various sizes were included for flour, sugar, etc. and were best when they could slide forward on ball bearings and be lined with zinc or similar metal. Frederick specified 3-inch deep drawers for kitchenware and 5-inch deep drawers for linens.

Frederick included prices for materials and a complete listing of what equipment and utensils were needed and where to place them in the kitchen. All a would-be homeowner needed was 
to purchase well-made items from the list and then place them appropriately for a well-ordered and efficient kitchen. ${ }^{12}$

\section{THE ARCHITECTS' SMALL HOUSE SERVICE BUREAU}

The purpose of Frederick's course textbook parallels the Architects' Small House Bureau's (ASHSB) intents. Beginning in 1919, a group of Minnesota architects banded together to improve housing stock in the United States through good design. The ASHSB held as its mission to produce affordable, small, and well-designed houses available to all. The commitment to good design included a vast campaign to educate builders and homeowners about the value of design and why a trained designer was needed for a successful, affordable, and comfortable residence. Between 1919 and 1937 the architect members of ASHSB produced hundreds of unique house plans, which could be purchased and tailored to a specific site, and published them in plan books, magazines, and newspapers across the U.S. and Canada. Each book of house designs included written guidance for the specific design and general information for homeowners and builders. The ASHSB eventually had several regional offices across the country and hundreds of members. Many of the designs were built in North America.

In addition to the production of plans, the members of the ASHSB also dispensed a great deal of advice about the design of the kitchen. The first plan book, How to Plan, Finance and Build your Home (1921), included 99 house designs ranging from three to six principal rooms. The designs for these kitchens demonstrate a combination of current research of the day with an understanding of the principles of Taylor and the writings of Frederick, Child, and others.

The Frankfurt kitchen (1926) has long been recognized as one of the first designs to be strongly influenced by Taylorism and the subsequent work of Frederick; it is regarded as the best example of the application of scientific management to the residential kitchen. Looking at the ASHSB 1921 plan book provides an earlier example of Taylor's principles in the kitchen as adapted by Child, Frederick, and others.

\section{Brief History of the ASHSB}

From the beginning, the ASHSB was closely aligned with the Better Homes in America campaign started in 1921 in New York by Marie Melony. By 1924, the ASHSB was credited as the expert organization for competent house design within the guidebooks for the Better Homes Campaigns. As the designers for the Better Homes Campaign, ASHSB archived files contained the Better Home Campaign Guidebooks and reading lists. Of particular interest to kitchen designs and articles by ASHSB members was Helen Binkerd Young's Cornell Reading Course “Planning

$12 \quad$ Ibid the Home Kitchen" (1921). Young references both Child and Frederick as sources for her work. The analysis of ASHSB plans against Frederick's advice demonstrates that ASHSB members disregarded Frederick's advice related to the stove placement. Rather than including nearby work surfaces, the stove sits alone in all of the designs. Young's work may be the source of this. She specifically addressed this in her reading course: "Ordinarily, the stove or the range is the one piece of equipment that should be set somewhere apart. It may be conveniently placed in a detached position on a separate wall space, partly because the other work is more comfortable if the stove is not too near, and partly because the stove is such that two or three sides must be accessible to the worker. In general, then, the stove should not be located too near the other pieces of equipment, for it will crowd the work and make ugly the corners to clean."13 (See Figure 8)

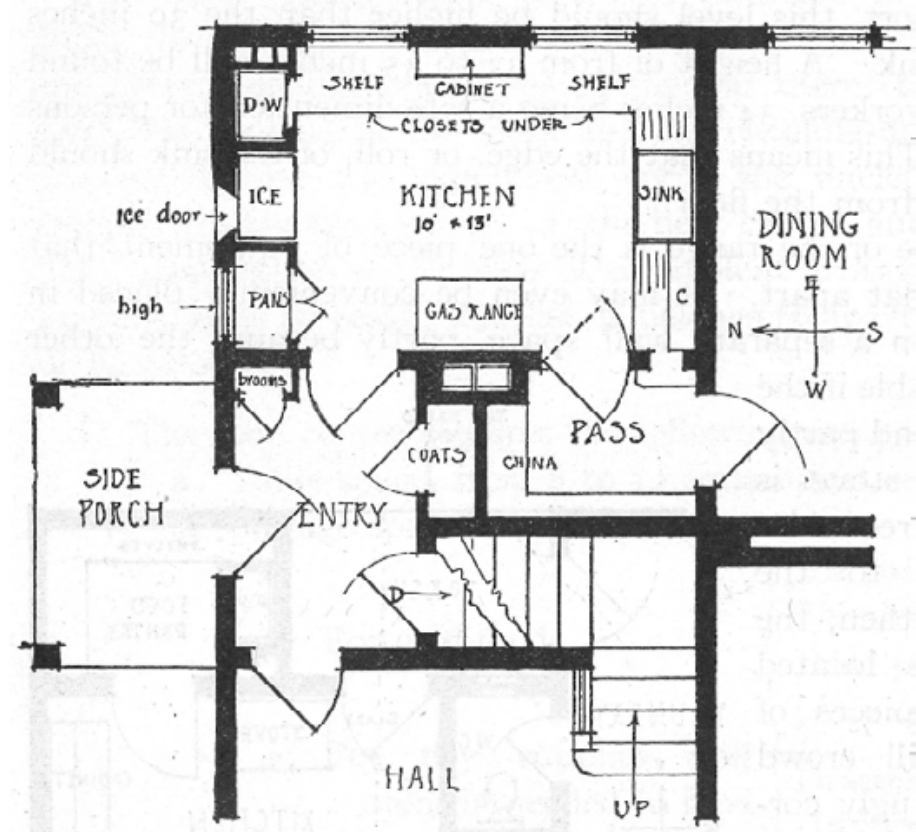

Fig. 28. A Kitchen For a SUbURban house, DEVELOPED IN ACCORDANCE WITH THE PRINCIPLES OF GOOD ARRANGEMENT The equipment is built in place; the fuel used is gas

Figure 8: Helen Binkerd Young, "The Planning of the Home Kitchen." The Cornell Reading Course for the Farm Home, Lesson 108, July 1916.

\section{Research Method}

For this research, a plan content analysis instrument was developed using 75 different variables outlined by Frederick for proper kitchen design. An earlier version of the instrument was

$13 \quad$ Helen Binkerd Young, "The Planning of the Home Kitchen." The Cornell Reading Course for the Farm Home, Lesson 108, July 1916. Although this references the farm home, designs for both suburban home kitchens and farm house kitchen are provided. This resource was originally overlooked since it references only the farm kitchen in the title. 
tested on ten of the designs (a few of each house size-three room, four room, five room, and six room plans) and then modified to accommodate additional variables such as freestanding stoves, which Frederick did not recommend. The first set of characteristics (18 variables) included plan size, shape, and layout with routing for food preparation and cleanup delineated (paths $A$ and $B$ ). The author did plan sketches of the 99 plans showing the routing for $A$ and $B$ (see Figure 9). Individual appliances and storage of specific items, location, and size represented another seven variables; finishes, five variables; lighting and ventilation, five variables; and the remaining 40 variables related to a textual analysis of words used by Frederick in the essays and written descriptions. These included references to labor saving, step saving, and other words about efficiency. The 99 designs from How to Plan, Finance and Build your Home were analyzed using the multivariable plan content analysis tool. All 99 plans were unique with the exception of two designs that repeated a variation on a particular kitchen design. It should be noted that the individual house plan designs did not include discussions of interior finishes or specific storage guidance. This was included

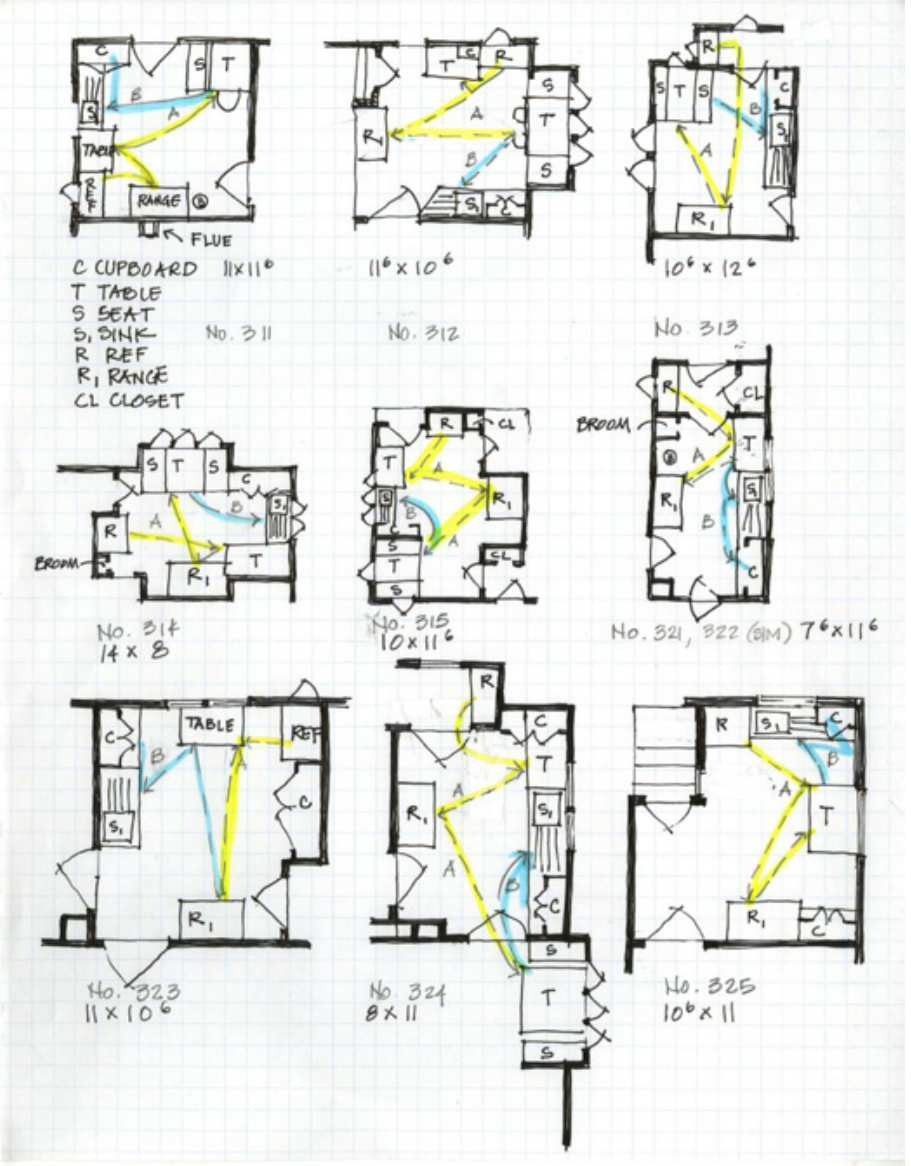

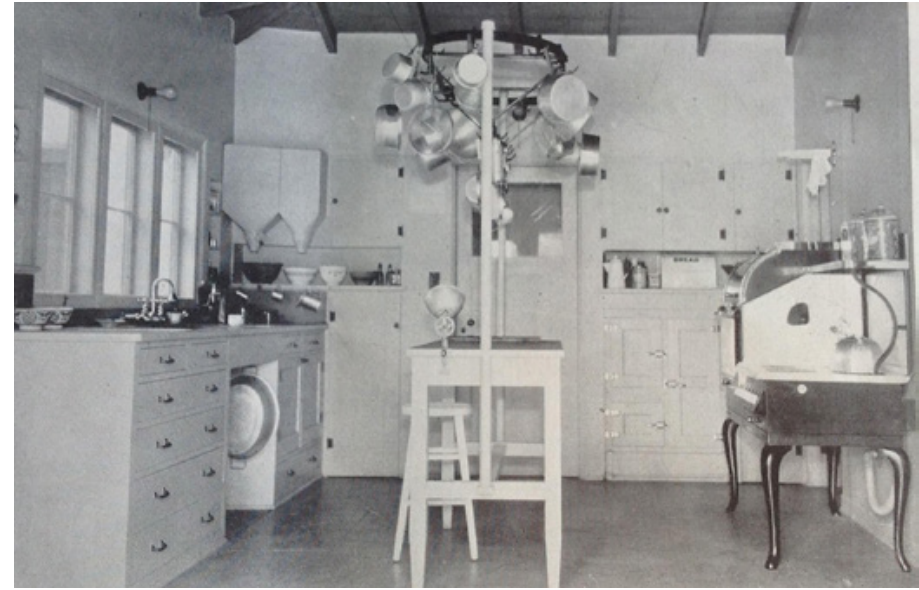

Figure 10: ASHSB kitchen interior.

within the articles contained in the plan book. The articles were used to expand the brief descriptions accompanying each design. In addition to this, all ASHSB members had checklists from the organization about what to include in actual plan sets including specific cabinet organizations as seen in Figure 10.

Each design included an overall plan for each floor level, an exterior perspective view and a written description of the house that also mentions the kitchen (approximately two long paragraphs describing the entire design). The plans ranged in size from three principal rooms up to six principal rooms. Two essays were included in the book that pertained to kitchen design: one on kitchen arrangement and one on painting.

Since interior elevations did not accompany the designs, all information on shelving, storage, and appurtenances was from the plan view, the description and the accompanying essay on kitchen design. The three-paged essay, entitled "Your Kitchen Planned to Save Time, Steps, Labor: the latest up-to-date ideas on kitchen arrangement, 'routing steps,' grouping tools to save miles of needless walking," outlines the latest ideas in kitchen design including the need for smaller compact kitchens, the grouping of functions and the heights for countertops. The other article, entitled "Painting your Home-Inside and Out: The reasons why paint is used on the inside and outside of homes," provided color and finish information.

Once it was determined that all 99 designs had free-standing stoves, sources for the kitchen design were expanded to include Helen Binkerd Young's work that interprets and combines Frederick's early work with that of Georgie Boynton Young.

Figure 9: Analysis diagrams by author. 


\section{FINDINGS}

The findings of the design and essay content analysis are presented using groupings similar to those used by Frederick. A summary of the most commonly occurring of the variables is presented in Table 1.

Table 1: Attribute Analysis

\begin{tabular}{|c|c|c|}
\hline Attribute & $\begin{array}{l}\text { Design } \\
\text { instances }\end{array}$ & $\%$ \\
\hline \multicolumn{3}{|l|}{ Size } \\
\hline $9 \times 11$ (99 sqft) & 12 & 12 \\
\hline $11 \times 13$ (Frederick, Boynton, and Young) (143) & 1 & 1 \\
\hline $14 \times 16(224)$ & 0 & 0 \\
\hline $18 \times 18(324)$ & 0 & 0 \\
\hline 99-324 sqft (Frederick range) & 99 & 100 \\
\hline $10 \times 12$ (Boynton and Young) (120) & 5 & 5 \\
\hline $9 \times 12$ (Young) (108) & 3 & 3 \\
\hline $10 \times 13$ (Young) (130) & 4 & 4 \\
\hline $10 \times 14$ (Young) (140) & 1 & 1 \\
\hline 11 x 11 (Young) (121) & 5 & 5 \\
\hline $11 \times 12$ (Young) (132) & 1 & 1 \\
\hline $12 \times 12$ (Young) (144) & 0 & 0 \\
\hline Frederick sizes & 13 & 13 \\
\hline Boynton sizes & 5 & 5 \\
\hline Young sizes & 20 & 20 \\
\hline Other sizes (in range) & 64 & 64 \\
\hline Counter height & 34-99" & 100 \\
\hline \multicolumn{3}{|l|}{ Layout } \\
\hline Areas (2): food/clean & 99 & 100 \\
\hline Proper layout A/B & 99 & 100 \\
\hline \multicolumn{3}{|l|}{ Lighting } \\
\hline \multicolumn{3}{|l|}{ Over stove } \\
\hline Window over sink & 88 & 89 \\
\hline Window over work areas & 76 & 77 \\
\hline Ventilation window & 99 & 100 \\
\hline Chimney-flue vent & 99 & 100 \\
\hline Window $42-46$ " above finished floor & 99 & 100 \\
\hline \multicolumn{3}{|l|}{ Finishes } \\
\hline \multicolumn{3}{|l|}{ Floor } \\
\hline Floor-tile & essay & -- \\
\hline Linoleum & essay & -- \\
\hline Composite floor & essay & -- \\
\hline
\end{tabular}

\begin{tabular}{|c|c|c|}
\hline Other? & -- & -- \\
\hline \multicolumn{3}{|l|}{ Walls } \\
\hline Wall-tile & essay & -- \\
\hline Oil cloth & essay & -- \\
\hline Paint flat & essay & -- \\
\hline Other? & -- & -- \\
\hline \multicolumn{3}{|l|}{ Color } \\
\hline Wood light & essay & -- \\
\hline Walls light & essay & -- \\
\hline Ceiling white & essay & -- \\
\hline Wainscot darker & essay & -- \\
\hline Avoid large patterns & essay & -- \\
\hline \multicolumn{3}{|l|}{ Table top } \\
\hline Vitrified glass & essay & -- \\
\hline Porcelain & essay & -- \\
\hline Monel metal & essay & -- \\
\hline Plate glass & essay & -- \\
\hline \multicolumn{3}{|l|}{ Serving } \\
\hline Galvanized iron & essay & -- \\
\hline Zinc & essay & -- \\
\hline Monel metal & essay & -- \\
\hline German silver & essay & -- \\
\hline Veg prep 8" hole & $N / A$ & -- \\
\hline \multicolumn{3}{|l|}{ Drain area } \\
\hline Zinc & -- & -- \\
\hline Porcelain & 99 & 100 \\
\hline German silver & -- & -- \\
\hline Copper & -- & -- \\
\hline \multicolumn{3}{|l|}{ Storage } \\
\hline Shelf sizes: $6,8,10,14 "$ & essay & \\
\hline Perm shelves to left of sink & 73 & 73 \\
\hline Pot closet to left of sink & 73 & 73 \\
\hline Sliding bins for flour, sugar & essay & \\
\hline \multicolumn{3}{|l|}{ Sinks } \\
\hline $\begin{array}{l}\text { Country } \\
\text { Slate, soapstone }\end{array}$ & $N / A$ & $\mathrm{~N} / \mathrm{A}$ \\
\hline $\begin{array}{l}\text { City } \\
\text { White enamel with drain }\end{array}$ & 99 & 100 \\
\hline Hot water heater/boiler & 65 & 65 \\
\hline \multicolumn{3}{|l|}{ Terms } \\
\hline Organized & 0 & 0 \\
\hline Efficient & 9 & 9 \\
\hline
\end{tabular}




\begin{tabular}{|l|l|l|}
\hline Well-planned & 39 & 39 \\
\hline Woman/housewife & 26 & 26 \\
\hline In kitchen dining & 20 & 20 \\
\hline Dining alcove & 8 & 8 \\
\hline Nook in living room & 9 & 9 \\
\hline Dining room & 59 & 60 \\
\hline No mention of dining & 3 & 3 \\
\hline Save steps & 25 & 25 \\
\hline Save labor & 29 & 29 \\
\hline Save time & 4 & 4 \\
\hline "Modern" & 15 & 15 \\
\hline Save money & 4 & 4 \\
\hline Well-lighted & 21 & 21 \\
\hline Sunny & 31 & 31 \\
\hline Cupboards/storage & 25 & 25 \\
\hline Stand-alone stove & 99 & 100 \\
\hline
\end{tabular}

\section{Plan Size and Layout}

Frederick's writing and the mission of the ASHSB are aligned in the need for a small and efficient kitchen. One hundred percent of the plans fitted within Frederick's recommended square footage range in The New Housekeeping (99-324 square feet) with most of the kitchen plans under Frederick's initial proposal of 120 square feet. The size of the 99 kitchen designs in How to Plan, Finance and Build Your Home ranged from 76 square feet to 224 square feet. All but three layouts were below 145 square feet, with an average size of around 100 square feet. The three larger layouts included dining areas for up to five people in the kitchen and were contained in the largest house designs. Following the initial analysis of size and square footages, a second set of variables was added to include plan sizes recommended by Young and Child. These revealed that Young's specific kitchen dimension recommendations were used $20 \%$ of the time, Frederick's recommendations were used $13 \%$ of the time, and Child's only $5 \%$ of the time.

All the plans appear to keep the food preparation routes and clean up routes mostly separated. This is reiterated in the written materials in the ASHSB plan book. According to the ASHSB essay:

There should be a systematic, well studied sequence or 'route' through which the housekeeper travels in preparing, serving and clearing away a meal. Considering the use and purpose of essential kitchen equipment, it has been found that the following sequence provides a maximum time and labor saving arrangement-icebox, kitchen cabinet, stove, work table to dining room. Following the meal the steps or sequence should be from dining room to work table or counter for soiled dishes, sink, drain board, china closet. This 'routing' is so arranged that work proceeds from right to left, leaving the dishes after drying in or near the dining room. In other words, the clearing away of a meal should go on from and return to the dining room in a direction opposite the movement of the hands on a clock. ${ }^{14}$

The most significant deviation from Frederick's advice was found in the location of the stove. All 99 plans by ASHSB members had stand-alone stoves without an adjacent worktable as recommended by Frederick. This stand-alone location follows the advice of both Young and Child.

Frederick's theory was that "the 'routing' or step-saving method requires separate surfaces for each purpose." ${ }^{15}$ These surfaces (including large equipment) should be grouped in direct and continuous routes that trace food preparation and clean up processes. Storage of supplies, small equipment and utensils should be grouped in the areas where they are needed. Failure to group large equipment, work surfaces, and storage areas appropriately results in wasted movements and requires extra energy.

Right to left was the direction recommended for the clean up route (scraping, dishwashing, draining, and shelving) based on a right-handed worker seated on a stool at the sink. There was no mention in Household Engineering of direction of the food preparation route. If the sink had double drain boards and the location of dish shelving and pot closet was not identified, it was not possible to determine if a kitchen plan followed this recommendation. Use of the plural nouns "activities" and "steps" might suggest an expectation that both clean up and preparation route should flow from right to left.

In the ASHSB plans locations of refrigerators and tables or work surfaces reflected Frederick's routing, but the range was isolated and there was no identification of serving or scraping surfaces. Specific information about how countertops and cabinets were used, and information about where preparation, serving, and storage processes occurred, and whether small equipment and utensils were grouped appropriately, were absent from the drawings but were discussed in the text. Photographs of actually constructed kitchens showed some of these features. For this

14 ASHSB, "Your Kitchen Planned to Save Time, Steps, Labor: The latest up to date ideas on kitchen arrangement, 'routing steps,' grouping tools to save miles of needless walking." How to Plan, Finance and Build Your Home (New Orleans, Louisiana: Southern Pine Association, 1921), 129-131.

15 Frederick, Household Engineering, 25. 
work, it was assumed that a cabinet between refrigerator and table or table and sink held supplies and preparation equipment and, similarly, a cabinet near the dining room door would have serving dishes.

Seventy-three percent of the designs placed permanent shelves and/or the pot closet to the left of the sink as recommended by Frederick. One hundred percent of the plans incorporated a white enamel sink (for a modern kitchen), many with drain boards on both sides as preferred by Frederick. Eighty-eight percent of the designs included a window over the sink for light and ventilation while seventy-seven percent also had a window over the work area for natural light. Written descriptions mentioned saving labor $29 \%$ of the time, saving steps $25 \%$ of the time, and improved arrangement and planning $44 \%$ of the time. Fifty-two percent of the descriptions mentioned the good lighting and or sunny interior of the kitchen.

\section{Other considerations}

The ASHSB article from the plan book included details on tool grouping, shelf sizes, drain boards, cross ventilation, materials, and color, reflecting many of Frederick's headings. As a point of variation from Frederick's guidance, about one third of the ASHSB plans had a fold down ironing board (32\%) in the kitchen despite Frederick's advice to keep other functions-such as laundryout of the food preparation area. ${ }^{16}$ One ASHSB design included washtubs in the kitchen.

Lighting and Ventilation Frederick recommended good lighting and cross ventilation for the kitchen, including windows. Descriptions for the ASHSB designs mentioned good lighting and/or sunny interior of the kitchen $52 \%$ of the time. Windows over sinks for light and ventilation occurred $88 \%$ of the time. Additionally, the sink and work table were located near a window with windows above the sink in the majority of the designs. Windows were included over the work area for natural light in $77 \%$ of the designs.

Materials, Finishes, and Color Frederick recommended flat plaster with flat paint on kitchen walls and preferred tile to other wall finishes. The ASHSB article included details on materials and color. According to the ASHSB advice, walls should have been either painted with oil or enamel paint, dull gloss or have washable oil cloth, Keene's cement, or tile for walls. Frederick preferred tile but accepted oil cloth or hard trowel plaster but did not specify Keene's cement.

The ASHSB color schemes were bright and cheerful: putty, sand, cream, warm gray, gray-blue, talon, darker trim; and all white for "the young." These were similar to Frederick's recommendations but lacking yellow and apple.
16 designs.
Sinks, Work Surfaces, and Stools Frederick recommended a white enamel sink for the city house as well as drain boards on both sides if possible. All 99 designs had a white enamel sink with an integrated drain board, and several included this feature to both sides. While Frederick provided a range of counter top heights related to the height of the worker, all cabinet work surface heights for ASHSB kitchens were standardized to 34 inches. Stools were located in many of the designs and were shown in interior photographs of the built designs.

Storage and Utensils Following several of Frederick's storage recommendations, permanent shelves and/or pot closets were located at left of sink $73 \%$ of the time. Additionally, a graded arrangement of shelves was provided for specific items. The specific shelf height dimensions for specific items-4", 6", 8"and what each should contain differed slightly from Frederick's recommendations.

Labor-Saving and Efficiency Issues The ASHSB made direct reference to Frederick's work in saying that an estimated $70 \%$ of the housekeeper's day was spent in the kitchen, a statistic given by Frederick. ${ }^{17}$ The design of a small and efficient kitchen was the focus of the ASHSB article entitled "Your Kitchen Planned to Save Time, Steps, Labor." The three-paged essay outlines the latest ideas in kitchen design including the need for smaller compact kitchens, the grouping of functions and the heights for countertops. According to the ASHSB, women desired anything designed to make their work easier and faster. According to the writer, "Every housekeeper loves a bright, sunny, cheerful kitchen. She deserves this kind of kitchen. But she also needs one that minimizes every motion, every step." ${ }^{18}$ The essay cites contemporary research studies wherein a "domestic science expert" counted steps and estimated that a housekeeper walked an extra 105 miles per year in an inefficient layout. The "routing" of the kitchen in a smaller layout could reduce this extra effort. The article includes several details that reflect Frederick's advice including information on tool grouping, shelf sizes, drain boards, cross ventilation, materials, and colors. As Frederick preferred, the ASHSB also routed activities and steps right to left. Like Frederick, a specific preference for the double drain board was included. The graded arrangement of shelves for specific items was recommended as follows: a 4-inch shelf for glass jars; a 6-inch shelf for glasses, cups, and small dishes; and an 8-inch shelf for plates and chinaware. All rooms needed an abundance of light, cross ventilation and an appropriate cheerful color scheme-all ideas promoted by Frederick.

17 Architects' Small House Service Bureau, How to Plan, Finance and Build Your Home (New Orleans, Louisiana: Southern Pine Association and the Architects' Small House Service Bureau, 1921), 129; Frederick, Household Engineering, 19.

18 ASHSB, 129. 


\section{CONCLUSIONS}

It is clear when reading the works of the ASHSB and viewing the range of kitchen designs, that the work the members created was informed by Frederick and her contemporaries in home efficiency and domestic engineering. The notion that homemaking was an authentic occupation and could be guided by Taylor's principles of efficiency was a radically new way of considering and then designing the home.

Some variations not following Frederick's advice also occurred which illustrate a familiarity with the work of others such as Young, who interpreted both Child and Frederick in her own correspondence course for Cornell. The designs were undoubtedly impacted by the opinions of the architects designing the homes as well.

As some of the earliest American applications of the home economist scientific principles of kitchen design, the plans of the ASHSB had a significant impact on the arrangement of the kitchen in the 1920s. Hundreds of plan sets were sold throughout the United States (and Canada) along with subscriptions to The Small Home, the reproduction of these plans in newspapers and magazines, and the plan books produced by the ASHSB. While Frederick may not have been the only influence on the kitchen designs by the ASHSB members, her concepts were evident in the designs and the kitchen layouts produced. These findings show that Taylor's principles and his female followers in domestic engineering had an impact on architect-designed houses as early as 1921.

\section{Future Directions}

One area of research that would contribute to this study and the work on the Architects' Small House Service Bureau would be to look at the gender issues involved in male architects designing kitchens for female housewives using Taylor-based principles. Although no comprehensive list of all ASHSB members was located in the archives, all members' names mentioned in correspondence, memorandums, and meeting minutes were men. Females were sometimes engaged to write articles related to decorating, color, and home arrangement, but it is unclear whether they did any space planning for any of the designs based on the research completed thus far.

\section{REFERENCES}

Architects' Small House Service Bureau. How to Plan, Finance and Build Your Home. New Orleans, Louisiana: Southern Pine Association and the Architects' Small House Service Bureau, 1921.

Catharine Beecher and Harriet Beecher Stowe. The American Woman's Home or Principles of Domestic Science. Boston: A.H. Brown and Company, 1869.

Genevieve Bell and Joseph Kaye. "A Kitchen Manifesto," Gastronomica (Spring 2002): 46-62.

Georgie Boynton Child. "The New Housekeeping Movement," The Independent Weekly Magazine, New York, Vol. LXXII (1912): 1000-1004.

Georgie Boynton Child. The Efficient Kitchen: Definite Directions for the Planning, Arranging and Equipping of the Modern LaborSaving Kitchen-A Practical Book for the Homemaker, New York: McBride Nast and Company, 1914.

Christine Frederick. The New Housekeeping: Efficiency Studies in Home Management Garden City, New York: Doubleday Page and Company, 1913.

Christine Frederick. Household Engineering: Scientific Management in the Home. Chicago: American School of Home Economics, 1915, 1919, 1920.

Laurel Graham. "Domesticating Efficiency: Lillian Gilbreth's Scientific Management of Homemakers," Signs, Vol. 24, No. 3 (1999): 633-675.

Frederick Taylor. The Principles of Scientific Management. New York: Harper Bros., 1911.

Helen Binkerd Young. "The Planning of the Home Kitchen." The Cornell Reading Course for the Farm Home, Lesson 108, July 1916. 